\title{
ANALYSIS OF DYNAMICS OF PEER-TO-PEER NETWORK STATE DURING TRANSMISSION OF LIVE STREAMING VIDEO
}

\author{
V.V. Popovskyy, K.O. Popovska \\ Kharkiv National University of Radio Electronics, Kyiv, Ukraine
}

Objective. The aim of the paper is the analysis of peer-to-peer network functioning quality in various load modes.

Methods. A calculation of the selected quality index for various intensities of the occurrence of peers in the network based on the mathematical model of the network state and the solution of the integro-differential equation of dynamics is performed.

Results. The analysis of the developed model has shown that in stationary operation conditions the quality as the relative value of upload and download speeds to the number of active peers in the network increases as the total amount of content offers increases. In conditions of non-stationarity, during periods of mass connection of new peers, the quality of the network may drop. Providers should encourage the altruistic strategy of peers.

Conclusions. Analytical dependence of the peer-to-peer P2P network quality of broadcasting live streaming video on the components of this network has been obtained. Peer-to-peer P2P Internet networks provide a very popular service for the real time TV content delivery. Users of the P2P network in order to improve the quality of use should not immediately leave the network, which enables other peers to download the necessary fragments.

Keywords: Peer-to-peer networks; quality of functioning; integro-differentiated model; altruistic strategy.

\section{Introduction}

Peer-to-Peer (P2P) file systems are overlay networks that work over the Internet $[1,2]$. The P2P network is a distributed system that contains interconnected nodes that are capable of self-organization into the network topology for the purpose of sharing resources such as content, processor cycles, storage devices, and bandwidth adaptable to failures and a variable number of nodes while maintaining an acceptable level of connectivity and performance without the need for intermediaries or support of the global central server.

The range of such systems for content distribution starts from relatively simple applications for direct file sharing and extends to more complex ones that create distributed storage environments that provide security and efficient organization, indexing, searching, updating and retrieving data. Examples include PPLive, PPStream, Napster, Gnutella, Kazaa, Freenet, Groove, etc. $[2,3,4]$. In the future, we will focus specifically on this class of networks.

Nowadays a large number of popular network services are based on P2P technology - from simple file sharing to voice and video communication. It is possible to perform distributed computing that allows users to utilize remote computers in order to perform complex data processing.

Distribution of resources, which occurred due to the emergence of peer-to-peer networks, led to the virtual disappearance of expenditures associated with maintaining a giant centralized infrastructure.

\section{Main part}

Dynamic characteristics of the peer-to-peer network are determined by the speed of the content download $V_{d}$ and its upload speed $V_{u}$. For a specific peer, these characteristics are determined as

$$
\begin{aligned}
& V_{d}=d \lambda_{d}(t) / d t, \\
& V_{u}=d \lambda_{u}(t) / d t,
\end{aligned}
$$

where $\lambda_{d}, \lambda_{u}$ are respectively the download and upload streams intensity.

In the balance ratio between upload and download speeds, the equality determines the video server upload speed

$$
\int_{0}^{N(t)} V_{u}(t, v) d v+U=\int_{0}^{N(t)} V_{a}(t, v) d v
$$

where $U$ is the download speed of the video server.

Each of ${ }^{i}$ - peers has its own strategy of behavior. In particular, completely egoistic strategy is possible, in which the peer only downloads the information at the speed $V_{u i}$, but it does not download on others $V_{u i}=0$. The degree of peer's egoism is determined by the speeds ratio:

$$
S(t)=V_{u}(t) / V_{d}(t)
$$

The index $S(t)$ can vary over the range from $S_{i}=0$ up to quite large numbers. At $S_{i} \geq 1$ the 
respective peer demonstrates a generous altruistic strategy. Obviously, the quality of the peer-to-peer network operation as a whole is determined by the values of this index reduced to the current number of active peers:

$$
Q(t)=\frac{1}{N} \sum_{i=1}^{N} S_{i}(t)
$$

where $N$ is the number of active peers, a variable quantity on which the quality depends $Q(t)$. With quite large number of peers, the sum can be replaced with the integral, and $N$ with $N(t)$. In this case (3) is represented in the form

$$
Q(t)=\frac{1}{N(t)} \int_{0}^{N(t)} S_{i}(t) t_{1} v d v
$$

We obtain an explicit dependence of the quality change $Q(t)$ on the parameters. To do this, we determine the derived function $Q(t)$. The differentiation of a composed function of several variables under the integral sign is a complicated problem, especially for the case when the integration limits depend on parameters. When determining the derivative, we assume that the function $N(t)$ is continuous on the interval of integration and has continuous derivatives. Due to this, the general equation of the differential has the form [Bronstein I.I., Semendyaev K.L., 1965 p.405]:

$\frac{d}{d y} \int_{\alpha(y)}^{\beta(y)} f(x, y) d x=\int_{\alpha(y)}^{\beta(y)} \frac{\partial f(x, y)}{\partial y} d x+\beta^{\prime}(y) f(\beta(y), y)-\alpha^{\prime}(y) f(\alpha(y), y)$.

As a result of differentiation (3), we obtain:

$$
\frac{d Q(t)}{d t}=-\frac{N^{\prime}(t)}{N(t)} Q(t)+\frac{1}{N(t)} \int_{0}^{N(t)} \frac{\partial S(t, v)}{\partial t} d v+\frac{N^{\prime}(t)}{N(t)} S(t, N(t)) .
$$

The equation (6) can be simplified taking into account the peer-to-peer network features. Let us take into account the fact that the peer which is again included in the network, does not have a resource for downloading yet, i.e. $S(t, v)=S(t, N(t))=0$ when $N(t=0)$

As a result, the derivative (6) takes the form:

$$
\frac{d Q(t)}{d t}=-\frac{N^{\prime}(t)}{N(t)} Q(t)+\frac{1}{N(t)} \int_{0}^{N(t)} \frac{\partial S(t, v)}{\partial t} d v .
$$

In the steady state of the peer-to-peer network, the streaming rate $V(t)$ is constant. Obviously, this assumption with the increasing number of peers becomes more and more correct due to averaging. Therefore, the replacement can be performed:

$$
\frac{d Q(t)}{d t} \cong-\frac{N^{\prime}(t)}{N(t)} Q(t)+\frac{1}{N(t)} \cdot \frac{1}{V_{d}} \int_{0}^{N(t)} \frac{\partial V_{u}(t, v)}{\partial t} d v .
$$

where $V_{d} \cong V_{d}(t)$ is the assumption of a constant download speed.
In terms of balance, the equality which determines the network responsiveness is hold

$$
\left(\int_{0}^{N(t)} \frac{\partial V_{u}(t, v)}{\partial t} d v\right) d t=-V_{d} N^{\prime}(t) d t .
$$

Therefore

$$
N^{\prime}(t)=\frac{1}{V_{d}} \int_{0}^{N(t)} \frac{\partial V_{u}(t, v)}{\partial t} d v
$$

By replacing $N^{\prime}(t)$ from (7), we obtain

$$
\frac{d Q(t)}{d t}=-\frac{N^{\prime}(t)}{N(t)} \cdot Q+\frac{N^{\prime}(t)}{N(t)} .
$$

The equation is satisfied with any ${ }^{t}$. By replacing $Q(t)$ and $N(t)_{\text {with }} Q\left(t_{0}\right), N\left(t_{0}\right)$ we obtain

$$
Q(t)=1-\frac{N\left(t_{0}\right)\left(1-Q\left(t_{0}\right)\right)}{N(t)}
$$

Obviously with increase of $N(t)$ the quality index $Q(t) \rightarrow 1$.

In view of $V_{d}(t, v)=V_{d}$, the balance condition (9) can be simplified:

$$
\int_{0}^{N(t)} V_{u}(t, v) d v+U=N(t) \cdot V_{d}
$$

Taking (4) into account, we obtain

$$
Q(t)=1-\frac{U}{V_{d} \cdot N(t)} .
$$

The monotonous growth of the $Q(t)$ index is caused by the increasing number of download offers. This is especially important for newly included peers that do not have video materials yet, which they could share with others.

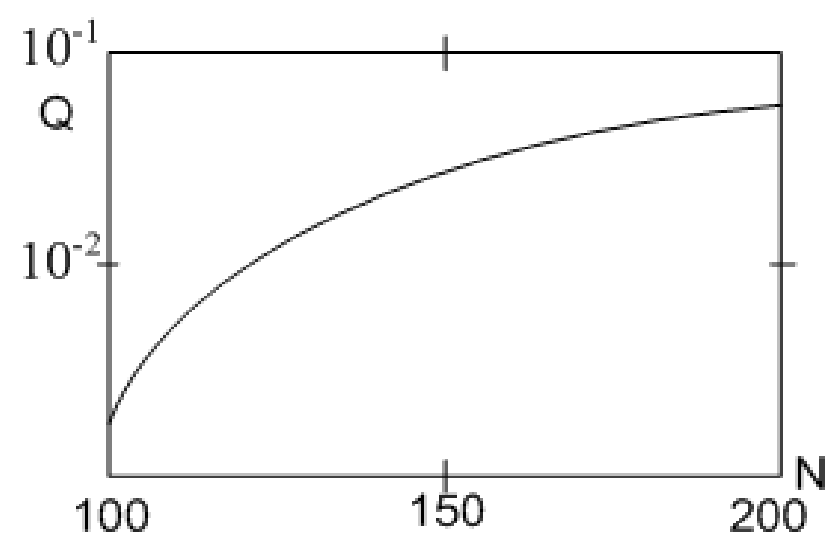

Fig. 1. Qualitative characteristic of the upload speed growth in a peer-to-peer network with an increase in the number of active peers

The idealized situation (15) in practice is limited to the maximum value of speed of loading, $V_{u} \leq V_{u \max }$ and as a result is limitation of network performance. 
Such phenomena happen often when some especially popular mass actions take place, to which consumers' interest increases sharply. Monotonous dependence (Fig.1) is violated.

We will consider the special case, when the mass connecting of new peers and system does not counteract to their connecting. In this case a quality index $Q(t)$ decreases, and on the basis of (7) we get

$$
d Q(t) / d t=\frac{N^{\prime}(t)}{N(t)} Q(t)
$$

This linear differential equalization will be transformed consistently in next forms:

$$
\frac{d Q(t) / d t}{Q(t)}=-d(\ln N(t)) / d t
$$

Finally:

$$
Q(t)=\frac{\exp ^{C}}{N(t)}, \quad \text { where } \quad C=\ln Q\left(t_{0}\right) N\left(t_{0}\right)
$$

$$
Q(t)=\frac{Q\left(t_{0}\right) N\left(t_{0}\right)}{N(t)}
$$

Thus in the conditions of the large avalanche loading current quality $Q(t)$ can decrease in $N(t) / N\left(t_{0}\right)$ times compared to quality that took place in the stationary mode of network functioning.

The graph of dependence of index of quality acquires other forms (Fig.2).



Fig.2. Dependence of quality index in the conditions of deficit in dynamics of loading and at avalanche demand on content
Thus mass appearance of new peers in the network that has no content for loading can result in the quality loss of network functioning. Gradually with a provision of a list of a few potential paternal peers watching the same channel by the server-tracker to each of new peers, position improves and the network obtains the stationary character. New peers begin to distribute the accumulated files to other interested peers while downloading. In addition, it is possible to avoid sharp decrease of the network performance presented by lower curves on Fig. 2 by temporally increasing the number of failures in the peak hours.

\section{Conclusion}

1. Analytical dependence of the peer-to-peer P2P network quality of broadcasting live streaming video on the components of this network has been obtained.

2. Peer-to-peer P2P Internet networks provide a very popular service for the real time TV content delivery.

3. Users of the P2P network in order to improve the quality of use should not immediately leave the network, which enables other peers to download the necessary fragments.

\section{References}

[1] Popovskij V., Barkalov A., Titarenko L. Control and Adaptation in Tel-ecommunication Systems. SpringerVerlag Berlin Heidelberg, 2011.p. 173

[2] http://www.internet2.edu/network/.

[3] http://datatracker.ieft.org/wg/alto/charter/.

[4] IETF REC 6972: Problem Statement and Requiremrents of the Peer-To-Peer Streaming Protocol (PPSP). [Electronic resource]. - available at: http://datatracker.ietf/doc/zfc6972/

[5] IETF Survey of P2P Streaming Applications [Electronic resource]. $\quad-$ available at: http://datatracker.ietf/doc/draft-ietf-PPSP-survey/ [6] Gaydamaka Yu.V. Data buffering model in streaming P2P networks / Yu.V. Gaydamaka, A.K. Samuylov // VSPU-2014. M., 2014. - P. 8656-8666.

Received in final form on May 06, 2017 


\section{Поповський В.В., Поповська К.О.}

Аналіз динамики стану пірінгової мережі під час передачі живого відео

Мета досліджень. Аналіз якості функціонування пирингової мережі в різних режимах навантаження.

Методика реалізації. На базі математичної моделі стану мережі та розв'язання інтегро-диференціального рівняння динаміки проведено розрахунок обраного показника якості для різних інтенсивностей появи пірів в мережі.

Результати досліджень. Аналіз розробленої моделі показав, що в умовах стаціонарного функціонування якість як відносна величина швидкостей завантаження і скачування відносно числа активних пірів в мережі збільшується, оскільки зростає загальний обсяг пропозицій контенту. В умовах нестаціонарності, в періоди масового підключення нових пірів, якість мережі може падати. Провайдерам слід заохочувати альтруїстичну стратегію пірів.

Висновки. Була отримана аналітична залежність якості відео трансляції в прямому ефірі в мережі Р2Р від компонентів цієї мережі. Інтернет-мережі Р2Р надають дуже популярну послугу для доставки телевізійного контенту в реальному часі. Для підвищення якості використання, користувачі мережі Р2P не повинні різко залишати мережу, що дозволяє іншим пірам завантажувати необхідні фрагменти.

Ключові слова: пирингові Р2Р-мережі; якість функціонування; інтегро-диференційована модель; альтруїстична стратегія.

\section{Поповский В.В., Поповская К.О.}

\section{Анализ динамики состояния пиринговой сети при передаче живого видео}

Цель исследований. Анализ качества функционирования пиринговой сети в различных режимах нагрузки.

Методика реализации. На основании математической модели состояния сети и решения интегродифференциального уравнения динамики произведен расчет выбранного показателя качества для различных интенсивностей появления пиров в сети.

Результаты исследований. Анализ разработанной модели показал, что в условиях стационарного функционирования качество как относительная величина скоростей скачивания и загрузки к числу активных пиров в сети, увеличивается, поскольку возростает общий объем предложений контента. В условиях нестационарности, в периоды массового подключения новых пиров качество сети может падать. Провайдерам следует поощрять альтруистическую стратегию пиров.

Выводы. Была получена аналитическая зависимость качества видео вещания в прямом эфире в сети Р2Р от компонентов этой сети. Интернет-сети Р2Р предоставляют очень популярную услугу для доставки телевизионного контента в реальном времени. Для повышения качества использования, пользователи сети Р2Р не должны резко покидать сеть, что позволяет другим пирам загружать необходимые фрагменты.

Ключевые слова: пиринговые Р2Р-сети; качество функционирования; интегро-дифференцированная модель; альтруистическая стратегия. 